\title{
EDITORIAL
}

\section{Obituary - David Bennett}

\author{
Mervyn Singer ${ }^{* 1}$ and Andrew Rhodes ${ }^{2}$
}

Consultants and professors are often liked, respected, and admired but few are loved. The avalanche of tributes and accolades that have flooded in since the tragic and premature death of David Bennett demonstrates the intense warmth and affection in which he was held.

David qualified from the Middlesex Hospital, London, in 1963. He spent a year as a Fulbright scholar in the pulmonary physiology lab at Johns Hopkins in Baltimore but otherwise worked solely in leading London hospitals. In 1974, he became the first director of the intensive care unit at St. George's Hospital and, in 1997, professor of intensive care. After formally retiring in 2007, he maintained research and teaching interests as a visiting professor at Guy's and St. Thomas' Hospitals. He was one of the founding fathers of British critical care and a leading figure on the international stage.

His first paper was published in 1962 [1]. His pioneering work in hemodynamic monitoring and physiology began in the 1960s with seminal work on electrocardiography, Doppler ultrasound (suprasternal and esophageal), and pulmonary artery catheters, followed by studies with gastric tonometry, lithium dilution measurement of cardiac output and central venous oxygen saturation. He strongly promoted their incorporation into routine clinical practice, arguing cogently that guided physiological manipulation was superior to arbitrary and oftenmisplaced decision-making. He often used techniques of guided physiological manipulation to experiment on a wide range of then-novel pharmacological compounds, including nitroglycerin, dopexamine, new hydroxyethyl starches, pentoxifylline, esmolol, and carvedilol, and was the first to report the use of nitric oxide synthase inhibitors in patients with septic shock and this led to larger randomized trials. He championed the concept of perioperative circulatory optimization, initially proposed by William Shoemaker, to improve outcomes in high-risk surgical patients. Having confirmed the benefits in a landmark study that was published in the Journal of the

\footnotetext{
*Correspondence: m.singer@ucl.ac.uk

'University College London, Cruciform Building, Gower Street, London, WC1E 6BT, UK

Full list of author information is available at the end of the article
}

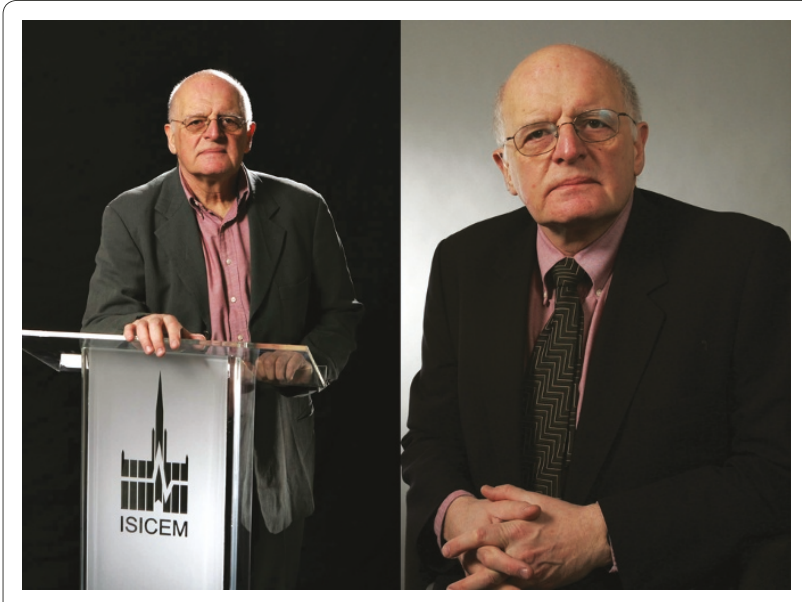

David Bennett.

American Medical Association in 1993 [2] and that was reinforced by subsequent studies, David became an impassioned advocate. More than anyone else, he put this concept on the map. A recent endorsement by the National Institute for Health and Clinical Excellence gave him enormous satisfaction.

He was a superb teacher, nurturing successive generations of grateful intensivists who progressed to successful research, clinical, and leadership careers in their own right. He organized events ranging from a European intensive care congress to highly successful summer schools in Brijuni, Croatia. He held important roles within the European Society of Intensive Care Medicine (ESICM) and in senior editorial positions for a variety of critical care journals, including cardiovascular section editor for Critical Care. The UK Intensive Care Society and ESICM both acknowledged his major contributions by awarding him honorary fellowships.

David inspired through passionate example. For him, heaven was an animated discussion surrounding a new concept, a trial design, an exciting research finding, or a controversial paper. Hell was the (rare) inability to elicit a response. He was intensely modest; even his close family was unaware of the scale of his achievements. David exuded humanity and loathed the mundane. Characteristically perhaps, the disease that defeated him, mastocytosis leading to a mast cell leukemia, was extremely 
rare. Though certainly not appreciating this nasty and aggressive illness, he was fascinated by its complexities and the therapeutic uncertainties, right up until the day of his death.

He leaves a wife, daughter, two grandchildren, and many other broken hearts.

\section{Author details}

'University College London, Cruciform Building, Gower Street, London, WC1E 6BT, UK. 'Department of Intensive Care Medicine, St. George's Healthcare NHS Trust, Blackshaw Road, London, SW17 0QT, UK
Published: 23 April 2012

\section{References}

1. Bennett ED, Jayson MI, Rubenstein D, Campbell EJ: The ability of man to detect added non-elastic loads to breathing. Clin Sci 1962, 23:155-162.

2. Boyd O, Grounds RM, Bennett ED: A randomized clinical trial of the effect of deliberate perioperative increase of oxygen delivery on mortality in highrisk surgical patients. JAMA 1993, 270:2699-2707.

doi: $10.1186 /$ cc11234

Cite this article as: Singer M, Rhodes A: Obituary - David Bennett. Critical Care 2012, 16:122. 